\title{
Profesyonel Sporcularda Fiziksel, Psikolojik, Ekonomik ve Cinsel Şiddetin Cinsiyet Değişkenine Göre İncelenmesi
}

\author{
Investigation of Physical, Psychological, Economic and Sexual Violence \\ in Professional Athletes in terms of Gender Variable
}

\author{
Gülsüm BAŞTUĞ ${ }^{*} i$ \\ Rüya BEYHAN ${ }^{* *}$ iD

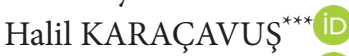 \\ Sinem $\mathrm{HEB}^{* * * *}$ (ID) \\ Fatih SALMAN $^{* * * * *}$ iD
}

\section{Öz}

$\mathrm{Bu}$ araştırma, profesyonel sporcularda fiziksel, psikolojik, ekonomik ve cinsel şiddetin cinsiyet değişkenine göre incelenmesi amacıyla yapılmıştır. Araştırmaya, yaş ortalaması $22.34 \pm 5.29$ olan, farklı spor branşlarından (Atletizm, Basketbol, Voleybol, Futbol, Fitness, Tenis, Boks), 68 erkek, 98 kadın olmak üzere toplam 166 sporcu katılmıştır. Sporcuların fiziksel, psikolojik, ekonomik ve cinsel şiddet düzeylerini belirlemek için araştırmacı tarafından ilgili literatür taraması (Bulut, 2012; Kılıç, 2019) yapılarak hazırlanan anket uygulanmıştır. Verilerin değerlendirilmesinde, frekans analizi, Crosstab ve $t$ testi analizleri uygulanmıştır. Sonuç olarak, sporculara fiziksel şiddeti uygulayan kişi olarak diğer (flört, arkadaş ve diğ.) seçeneğinden sonra antrenör seçeneğinin yüksek değerde olduğu tespit edilmiştir. Sporcular, psikolojik şiddete en fazla antrenör tarafından ve antrenmana geç geldiğinde maruz kaldığını belirtmiştir. Ekonomik şiddet boyutunda, spordan elde edilen ekonomik gelirin yetersiz olduğu, prim ve maaşların geciktirildiği veya verilmediği, takım içi ücret eşitsizliğinin olduğu belirlenmiştir. Cinsel şiddet boyutunda, cinsel şiddeti uygulayan kişi sorusuna diğer (flört, arkadaş ve diğ.) seçeneğinden sonra antrenör seçeneğinin yüksek değerde olduğu tespit edilmiştir. Psikolojik şiddet ve ekonomik şiddet boyutunda cinsiyet değişkenine

* Doç. Dr., Muğla Sıtkı Koçman Üniversitesi, Spor Bilimleri Fakültesi, gbastug@mu.edu.tr, https://orcid.org/0000-0001-7916-2042

** Yüksek lisans öğrencisi, Muğla Sıtkı Koçman Üniversitesi, Sağlık Bilimleri Enstitüsü, ruyabeyhan@posta.mu.edu.tr, https://orcid.org/0000-0002-5942-7039

*** Yüksek lisans öğrencisi, Muğla Sıtkı Koçman Üniversitesi, Sosyal Bilimleri Enstitüsü, halilkaracavus@posta.mu.edu.tr, https://orcid.org/0000-0002-6720-9226

**** Yüksek lisans öğrencisi, Muğla Sıtkı Koçman Üniversitesi, Sağlık Bilimleri Enstitüsü, sinemheb@posta.mu.edu.tr, https://orcid.org/0000-0002-5828-3029

***** Yüksek lisans öğrencisi, Muğla Sıtkı Koçman Üniversitesi, Sağlık Bilimleri Enstitüsü, fatihsalman@posta.mu.edu.tr, https://orcid.org/0000-0002-4437-5221 
göre anlamlı farklılık bulunmuştur. Erkek sporcuların ekonomik şiddete daha fazla maruz kaldığı, kadın sporcuların ise fiziksel ve psikolojik şiddete erkek sporculara göre daha fazla maruz kaldığı tespit edilmiştir. Anahtar Kelimeler: Sporcu, fiziksel, psikolojik, ekonomik, cinsel şiddet.

\begin{abstract}
This study was conducted to examine physical, psychological, economic, and sexual violence in professional athletes in terms of gender. A total of 166 active athletes, 68 men, and 98 women, from different sports branches (Athletics, Basketball, Volleyball, Football, Fitness, Tennis, Boxing), with an average age of 22.34 \pm 5.29 , participated in the study. To measure the physical, psychological, economic, and sexual violence dimension of the athletes, a questionnaire prepared by the researcher doing the relevant literature review (Bulut, 2012; Kılıç, 2019) was applied. In the evaluation of data, frequency analysis, crosstab, and t-test analyzes were applied. As a result, it was determined that the trainer option, after the other (dating, friend, etc.) option, was found to be of high value as the person who used physical violence to the athletes. Athletes stated that they were exposed to psychological violence most by the coach and when they came to training late. In the dimension of economic violence, it has been determined that the economic income obtained from sports is insufficient, premiums and salaries are delayed or not given, and there is inequality within the team. In the sexual violence dimension, it was determined that the trainer option was found to be of high value after the other (dating, friend, etc.) option to the question of the perpetrator of sexual violence. A significant difference was found in terms of psychological violence and economic violence according to the gender variable. It was found that male athletes were exposed to economic violence more, and female athletes were more exposed to physical and psychological violence than male athletes.
\end{abstract}

Keywords: Athlete, physical, psychological, economic, sexual violence

\title{
Gíriş
}

Dünya Sağllk Örgütü (DSÖ) şiddeti: ölüm, yaralanma, psikolojik zarar, kötü gelişme veya yoksunluk ile neticelenen veya sonuçlanma olasılığ 1 yüksek olan, tehdit edilen veya fiili olarak kendisine, başka bir kişiye veya bir gruba veya topluluğa karşı fiziksel güç veya gücün kasıtlı kullanımı olarak tanımlar (WHO, 2014). Uygulanan şiddet tipine göre yaptığımız sınıflamada ise şu alt başlıklar karşımıza çıkmaktadır; fiziksel şiddet, cinsel şiddet, duygusal şiddet, ekonomik şiddet, siber şiddet (Polat, 2014). Fiziksel şiddet en çok saptanan ve gözlenen şiddettir. Fiziksel güç kullanarak karşısındakini hırpalamak, dövmek eylemleriyle başlayan fiziksel şiddet ölümle sonuçlanan olaylara da neden olabilir (Neugebauer, 2000). Fiziksel şiddet toplumsal yaşamda ve sporda şiddetin en sık ve görünür şekli olarak karşımıza çıkmaktadır. Fiziksel şiddet daha çok bedene yöneliktir ve bedensel güce dayalıdır. Müsabaka esnasında sporcuların birbirlerine vurma, tekme atma, tükürme, yumruklama, yaralama gibi eylemler içerisine girmesi fiziksel şiddet olarak tanımlanır. Futbolcunun kale duvarlarını veya çimleri tekmelemesi, tenisçinin raketini yere vurarak parçalaması, seyircilerin oyunculara ya da hakeme pet şişe, bozuk para atmaları, sporda fiziksel şiddete örnektir. Sporda psikolojik şiddet; sporcunun, seyircinin, antrenörün rakibe, kendi takımının oyuncularına ya da hakeme küfür etmesi, bağırması, hakaret etmesi, onu aşağılaması, jest ve mimiklerle eleştirmesi şeklinde ortaya çıkabileceği gibi, müsabaka dışında da gerçekleşebilir. Antrenmanlarda ya da müsabaka arasında antrenörün kişiyi aşağılayıcı söylemlerde bulunması, aktif spor müsabakasına katılmasına fırsat vermemesi ve yedek oynatması da psikolojik şiddet olarak karşımıza çıkmaktadır. Spor müsabakalarında taraftar gruplarının birbirlerine, sporculara ya da hakeme yönelik aşağılayıcı, alaylı ve küfür içerikli söylemlerinin sıradanlaşması sporda psikolojik şiddetin normalleştirilmesine 
sebebiyet vermektedir. Sporda ekonomik şiddet; ekonomik kaynakların ve paranın sporcular üzerinde bir yaptırım, iktidar ve tehdit aracı olarak kullanılmasıdır. Elit spor bağlamında, sporcuların çalışma yaşamında ilerlemesine engel olma, maaşına, gelirine el koyma, az para verme, priminden kesme, prim sözü verip-prim vermeme, çok az para verip yapılması mümkün olmayan şeyleri talep etme, yedek oynatma, kadroya almama, sağlık hizmetlerinden yararlanmasını engelleme gibi söylem ve eylemlerle karşımıza çıkmaktadır. Diğer şiddet türleri ile bağlantı içerisinde olan ekonomik şiddet olgusu, sporcuların yaşam kalitesini, performansını ve motivasyonunu etkileyen olumsuz bir faktördür (Kılıç, 2019). Kişinin bir cinsel obje olarak görülmesi, gözle ya da sözle taciz edilmesi gibi durumlarda cinsel şiddet olarak değerlendirilmektedir (Kılıç, 2017). Tecavüz, sporcunun fiziksel veya duygusal baskıyla cinselliğe zorlanması, cinsellikte tamamen bir obje olarak kullanılması ve cinsel taciz bu şiddet türünün yansımalarıdır. Sporda cinsel şiddet olgusunu daha da netleştirmek gerekirse; seyircinin sporcunun belli cinsel bölgelerine odaklanması, fiziksel temas gerektiren sporlarda ya da antrenmanlarda antrenör sporcu arasında spor ahlakına aykırı eylemlerde bulunulması ve bu durumun meşrulaştırılması için sporcunun kariyeri üzerine tahakküm kurulması, sporla ilgili olmayan reklamlarda ya da programlarda sporcuların bir meta olarak kullanılmasi, kameraların sporcuların cinsel bölgelerine odaklanması gibi durumların birçoğu sporda cinsel şiddet unsuru olarak ele alınmalıdır (Kılıç, 2019). Türkiyede yapılan bazı çalışmalarda spor alanlarındaki şiddetin sorumlusu olarak; \%34,9 medya, \%21,6 kulüp yöneticileri, \%16,2 sorumsuz seyirciler, \%10,8 amigolar, \%6,6 taraftar dernekleri, \%5,8 hakemler ve \%4,1 oranında siyasiler olduğu belirlenmiştir. Antrenörler, her zaman farklı branşlarda önemli rol oynayan birincil aktörlerdir. Antrenörler tarafından desteklenen değerler ve beceriler, oyuncuların rakiplerine karşı nasıl oynadıklarını etkiler (Jamieson ve Orr, 2009). Antrenörler ve hakemler müsabaka ortamında sporcularla birlikte sonucu belirleyen aynı zamanda seyirciyi de etkileyen bireylerdir (Acet 2005; Arıkan 2007; Şahin 2003; Gümüşdağ 2004; Öztürk ve ark. 2004). Spor dalları açısından, mücadele sporları arasında yer alan futbol, basketbol, hentbol, boks ve buz hokeyi gibi dalların sporcularında şiddet daha büyük oranda görülmektedir. Oysa yüzme ve jimnastik gibi dallarda şiddet olaylarına rastlanmamaktadır (Tiryaki, 2000). Sporcular yarışmalar sırasında saldırgan olma eğilimindedirler (Widmeyer ve ark., 2002). İhmal ve fiziksel istismar gibi bazı şiddet biçimleri, cinsel şiddet kadar ilgi görmemiştir fakat şiddet sporda gerçek bir sorun teşkil etmektedir (Mountjoy ve diğ., 2016). Spor doğası gereği, istismara karşı büyük riskler barındırmakta olup sporun denetimsiz ortamında, küçük çocuklara bir temas firsatı doğmaktadır. Bu ortamlarda çocuklar hem fiziksel hem de duygusal istismara açıktır. Çocukların korunması ve hakları, antrenörlere yöneticilere çalışanlara, gönüllülere ve ailelere emanettir. Nitekim sporda çocuk istismarı olayları zaman zaman su yüzüne çıkmakta ve medyada yer bulmaktadır. Ancak maalesef bunlar sadece buz dağının görünen yüzünü oluşturmaktalar. (Domnhall, 1996). Sporda görülen fiziksel, psikolojik, cinsel, ekonomik şiddet olayları sporda çocuk koruma programını ortaya çıkarmıştır. Çocukların katılım sağladığı spor faaliyetlerini yöneten ve uygulayan bütün örgüt ve organizasyonlarda, çocuğun fiziksel, sosyal, duygusal, ekonomik, kültürel ve etnik olmak üzere tüm yönlerden korunması, spor organizasyonların da görev alan tüm unsurların konu hakkında eğitilmesi, çocuk istismarı olaylarının oluşmadan önlenmesi ve ihbarlara en hızlı ve uygun şekilde müdahale edilebilmesi için gerekli düzenlemelerin uygulamada ve hukuki zeminde sağlanması" şeklinde tanımlayabiliriz (Kerr, 2008; Brackenridge, 2012). Spor ortamlarında seyirci, hakem, 
sporcu, antrenör kaynaklı şiddet olaylarının gözlenmesi, basında ve sosyal medyada sıkça yer alan sporda şiddet haberlerinden yola çıkılarak, sporcuların kendi yaşantılarına ve gözlemlerine yönelik sorular ile şiddet boyutlarının incelenmesi düşünülmüştür. Daha önce yapılan çalışmalarda sporda şiddet olgusu; fiziksel, psikolojik, ekonomik ve cinsel şiddet boyutlarında derinlemesine bütüncül bir bakış açısıyla ortaya konulmamıştır. Şiddetin farklı boyutları ile incelendiği çalışmaların az ve sınırlı olması yapılan bu çalışmanın önemini artırmaktadır. Bu araştırma, profesyonel sporcularda fiziksel, psikolojik, ekonomik ve cinsel şiddetin cinsiyet değişkenine göre incelenmesi amacıyla yapılmıştır.

\section{YÖNTEM}

Bu çalışma, sporcu gençlere uygulanan şiddetin boyutlarını belirlemeyi amaçlayan bir betimsel araştırmadır. Tarama modelleri, geçmişte ya da halen var olan bir durumu var olduğu şekliyle betimlemeyi amaçlayan araştırma yaklaşımlarıdır. Araştırmaya konu olan olay, birey ya da nesne, kendi koşulları içinde ve olduğu gibi tanımlanmaya çalışılır (Karasar, 2005). Araştırmaya, yaş ortalaması 22.34 \pm 5.29 , spor yaşı ortalaması 2,27 $\pm 0,993$ olan, farklı spor branşlarından (Atletizm, Basketbol, Voleybol, Futbol, Fitness, Tenis, Boks), 68 erkek, 98 kadın olmak üzere toplam 166 sporcu katılmıştır. Katılımcılara çevrimiçi anket uygulanmıştır. Anket soruları araştırmacı tarafından ilgili literatür taraması (Bulut, 2012; Kılıç, 2019) yapılarak hazırlanmıştır. Araştırma doğrultusunda, fiziksel, psikolojik, ekonomik ve cinsel şiddet türlerinin sporcular üzerindeki etkisini ortaya koyabilecek temalara odaklanılmıştır. Soruların içeriğini sporcuların kişisel bilgileri yanında (yaş, cinsiyet, spor yaşı), şiddet ve şiddet türlerinin hakkındaki görüşleri oluşturmaktadır. Soruların içeriğini sporcuların yaşam öyküleri, şiddet ve şiddet türlerinin spor alanında etkileri hakkındaki görüşleri oluşturmaktadır. Bu bağlamda, sporda fiziksel şiddet, sporda psikolojik şiddet, sporda ekonomik şiddet ve sporda cinsel şiddet şeklinde dört ana tema belirlenmiştir. Literatür bilgilerine dayanılarak hazırlanan 49 soruluk anket katılımcıların maruz kaldıkları fiziksel, psikolojik, ekonomik ve cinsel şiddet hakkındaki soruları içermektedir. Ölçeğin Cronbach’s alpha değeri ,645 tir. Anket çalışması sonrasında elde edilen veriler SPSS 11 paket programı kullanılarak istatistik uzmanı yardımlarıyla analiz edilmiştir. Verilerin değerlendirilmesinde, frekans analizi, Crosstab ve $t$ testi analizleri uygulanmıştır.

\section{BULGULAR}

Tablo 1. Araştırmaya katılan sporcularda fiziksel şiddet boyutunun incelenmesi

\begin{tabular}{llll}
\hline & & n & \% \\
\hline Fiziksel şiddete maruz kaldınız mı? & Evet & 43 & 25.9 \\
& Hayır & 123 & 74.1 \\
\hline
\end{tabular}




\begin{tabular}{|c|c|c|c|}
\hline \multirow{5}{*}{ Fiziksel şiddet olarak en çok hangi davranışa maruz kaldınız? } & Tokat atma & 34 & 20.5 \\
\hline & Tekme atma & 34 & 20.5 \\
\hline & $\begin{array}{l}\text { Popoya vurma/ } \\
\text { Çimdikleme }\end{array}$ & 16 & 6.6 \\
\hline & $\begin{array}{l}\text { Sarsma/ Bir cisim ile } \\
\text { vurma }\end{array}$ & 9 & 5.4 \\
\hline & Hiçbiri & 99 & 59.6 \\
\hline \multirow{5}{*}{ Size fiziksel şiddet uygulayan kim di? } & Antrenör & 32 & 19.3 \\
\hline & $\begin{array}{l}\text { Beden Eğitimin } \\
\text { Öğretmeni }\end{array}$ & 13 & 7.8 \\
\hline & Takım arkadaşı & 7 & 4.2 \\
\hline & Seyirci & 6 & 3.6 \\
\hline & $\begin{array}{l}\text { Diğer (flört, arkadaş ve } \\
\text { diğ.) }\end{array}$ & 108 & 65.1 \\
\hline \multirow{5}{*}{ Fiziksel şiddetin performansınıza etkisi oldu mu? } & Hiç etkisi olmadı & 81 & 48.8 \\
\hline & Olumsuz etkiledi & 36 & 21.7 \\
\hline & Hirslandırdı & 23 & 13.9 \\
\hline & Olumlu etkiledi & 17 & 10.2 \\
\hline & $\begin{array}{l}\text { Sporu birakmayı } \\
\text { düşündüm }\end{array}$ & 9 & 5.4 \\
\hline \multirow[t]{2}{*}{ Takım arkadaşınız veya başka bir sporcu fiziksel şiddete maruz kaldı mı? } & Evet & 93 & 56.0 \\
\hline & Hayır & 73 & 44.0 \\
\hline \multirow{5}{*}{ Cevabınız evet ise fiziksel şiddeti uygulayan kim di? } & Antrenör & 50 & 30.1 \\
\hline & Beden Eğitimi Öğretmeni & 18 & 10.8 \\
\hline & Takım arkadaşı & 16 & 9.6 \\
\hline & Seyirci & 7 & 4.2 \\
\hline & $\begin{array}{l}\text { Diğer (flört, arkadaş ve } \\
\text { diğ.) }\end{array}$ & 75 & 45.2 \\
\hline
\end{tabular}

Tablo 1'de görüldüğü üzere, fiziksel şiddet olarak tokat atma ve tekme atma davranış1 \%20,5 oranında, fiziksel şiddeti uygulayan kişi olarak diğer (flört, arkadaş ve diğ.) seçeneği \%65,1 oranında, takım arkadaşına veya başka sporcuya fiziksel şiddeti uygulanma oranı \%56,0 ve fiziksel şiddeti uygulayan kişi olarak antrenör seçeneğinin \%30,1 oranında olduğu tespit edilmiştir. Fiziksel şiddeti uygulayan kişi olarak Antrenör seçeneğinin yüksek değerde olması da dikkat çekici bir bulgudur.

Tablo 2. Araştırmaya katılan sporcularda psikolojik şiddet boyutunun incelenmesi

\begin{tabular}{llll}
\hline & & n & \% \\
\hline Psikolojik şiddeti hangi nedenlerden dolayı maruz & Antrenmana geç geldiğimde & 142 & 85.5 \\
kaldınız? & Antrenmana gelmediğimde & 17 & 10.2 \\
& Antrenmanı bozan davranışlarda & 7 & 4.2 \\
\hline
\end{tabular}




\begin{tabular}{llll}
\hline \multirow{2}{*}{ Psikolojik şiddete en çok kim tarafından maruz } & Antrenör & 68 & 41.0 \\
kaldınız & Seyirci & 52 & 31.3 \\
& Takım arkadaşı & 19 & 11.4 \\
& Beden eğitimi öğretmeni & 15 & 9.0 \\
& Aile & 8 & 4.8 \\
& Yönetim & 4 & 2.4 \\
\hline Takım arkadaşınız veya başka bir sporcu psikolojik & Evet & 114 & 68.7 \\
şiddete maruz kaldı mı? & Hayır & 52 & 31.3 \\
\hline
\end{tabular}

Tablo 2’de görüldüğ̈ü üzere, sporcularda psikolojik şiddete maruz kalma oranı \%68,7, sporcular \%85,5 oranında antrenmana geç geldiğinde psikolojik şiddete maruz kaldığını belirtmiştir. Psikolojik şiddeti uygulayan kişi olarak antrenör \%41,0 oranında en yüksek değere sahip olduğu görülmektedir.

Tablo 3. Araştırmaya katılan sporcularda ekonomik şiddet boyutunun incelenmesi

\begin{tabular}{llll}
\hline & & $\mathbf{n}$ & \% \\
\hline Yaptığınız sporun karşıı̆̆ında verilen maddi karşılık sizi tatmin ediyor mu? & Evet & 43 & 25.9 \\
& Hayır & 123 & 74.1 \\
\hline Yönetim tarafından pirim ve maaşlarınız gecikmeden veriliyor mu? & Evet & 42 & 25.3 \\
& Hayır & 124 & 74.7 \\
\hline Takım içinde ücret eşitsizliği var mı? & Evet & 119 & 71.7 \\
& Hayır & 47 & 28.3 \\
\hline Kazanılan her maç sonrası maddi ödüller alıyor musunuz? & Evet & 43 & 25.9 \\
& Hayır & 123 & 74.1 \\
\hline Klüp tarafından size spor malzeme (ayakkabı, eşofman, yağmurluk vb) yardımı & Evet & 96 & 57.8 \\
yapılıyor mu? & Hayır & 70 & 42.2 \\
\hline Spordan kazandığınız ekonomik gelir ile asgari şartlarda & Evet & 36 & 21.7 \\
Yaşayabilir misiniz? & Hayır & 130 & 78.3 \\
\hline
\end{tabular}

Tablo 3’de görüldüğü üzere, sporcuların ekonomik şiddete maruz kalma oranları incelendiğinde, maddi karşılığın sporcuyu \%74,1 oranında tatmin etmediği, prim ve maaşların \%74,7 oranında geciktirildiği veya verilmediği, takım içi ücret eşitsizliğinin ise \%71,7 oranında, ekonomik gelir yetersizliğinin $\% 78,3$ oranında olduğu görülmektedir.

Tablo 4. Araştırmaya katılan sporcularda cinsel şiddet boyutunun incelenmesi

\begin{tabular}{llll}
\hline & & $\mathbf{n}$ & $\%$ \\
\hline \multirow{3}{*}{ Cinsel taciz/şiddet e maruz kaldınız mı? } & Hiçbir zaman & 151 & 91.0 \\
& Nadiren/ Bazen & 14 & 8.4 \\
& Her zaman & 1 & 0.6 \\
\hline
\end{tabular}




\begin{tabular}{|c|c|c|c|}
\hline \multirow{5}{*}{ Ne tür Cinsel taciz/şiddete maruz kaldınız? } & Sözlü taciz & 59 & 35.5 \\
\hline & Özel bölgelere dokunma & 39 & 23.5 \\
\hline & Tecavüz & 37 & 22.3 \\
\hline & Okşama/öpme & 21 & 12.6 \\
\hline & Röntgencilik & 10 & 6.0 \\
\hline \multirow{7}{*}{ Cinsel taciz/şiddeti uygulayan kim di? } & Antrenör & 46 & 27.7 \\
\hline & Seyirci & 14 & 8.4 \\
\hline & Takım arkadaşı & 13 & 7.8 \\
\hline & Kulüp Yöneticileri & 10 & 6.0 \\
\hline & Beden Eğitimi Öğretmeni & 9 & 5.4 \\
\hline & Aile & 8 & 4.8 \\
\hline & Diğer (flört, arkadaş ve diğ.) & 66 & 39.8 \\
\hline \multirow{2}{*}{$\begin{array}{l}\text { Takım arkadaşınız veya başka bir sporcu cinsel } \\
\text { taciz/ şiddete maruz kaldı mı? }\end{array}$} & Evet & 116 & 69.9 \\
\hline & Hayır & 50 & 30.1 \\
\hline \multirow{7}{*}{$\begin{array}{l}\text { Cevabınız evet ise cinsel taciz /şiddet uygulayan } \\
\text { kim di? }\end{array}$} & Antrenör & 25 & 15.1 \\
\hline & Beden Eğitimi Öğretmeni & 12 & 7.2 \\
\hline & Aile & 7 & 4.2 \\
\hline & Seyirci & 5 & 3.0 \\
\hline & Takım arkadaşı & 3 & 1.8 \\
\hline & Kulüp yöneticisi & 2 & 1.2 \\
\hline & Diğer (flört, arkadaş ve diğ.) & 112 & 67.5 \\
\hline \multirow{2}{*}{$\begin{array}{l}\text { Spor ortamlarında kendinizi cinsel bir obje gibi } \\
\text { hissediyor musunuz? }\end{array}$} & Evet & 20 & 12.0 \\
\hline & Hayır & 146 & 88.0 \\
\hline
\end{tabular}

Tablo 4'de görüldüğü üzere, sporcuların cinsel şiddet boyutu incelenmiş ve takım arkadaşı veya başka bir sporcunun cinsel şiddete maruz kalma oranı \%69,9 oranında, sözlü cinsel şiddete maruz kalma \%35,5 oranında, özel bölgelere dokunma \%23,5 oranında, cinsel şiddeti uygulayan kişi olarak antrenör seçeneği \%27,7 oranında olduğu tespit edilmiştir. Cinsel şiddeti uygulayan kişi sorusuna diğer (flört, arkadaş ve diğ.) seçeneği \%39,8 oranında en yüksek değere sahiptir.

Tablo 5. Fiziksel şiddetin cinsiyet değişkenine göre dağılımı

\begin{tabular}{lllll}
\hline Değişkenler & & Evet & Hayır & \\
\hline Cinsiyet & Kadın & 27 & 71 & 98 \\
& Erkek & 16 & 52 & 68 \\
Toplam & & 43 & 123 & 166 \\
\hline
\end{tabular}

Tablo 5'de görüldüğg̈ üzere, fiziksel şiddet boyutunda erkek ve kadın sporcuların olumsuz yanıt oranı yüksek olmakla birlikte, kadın sporcularda fiziksel şiddet değerinin daha yüksek olduğu görülmektedir. 
Tablo 6. Psikolojik şiddetin cinsiyet değişkenine göre dağılımı

\begin{tabular}{lllll}
\hline Değişkenler & & Evet & Hayır & \\
\hline Cinsiyet & Kadın & 37 & 61 & 98 \\
& Erkek & 35 & 33 & 68 \\
Toplam & & 72 & 94 & 166 \\
\hline
\end{tabular}

Tablo 6'de görüldügü üzere, psikolojik şiddet boyutu erkek ve kadın sporcuların olumsuz yanıt oranı yüksek olmakla birlikte, kadın sporcularda psikolojik şiddet değerinin daha yüksek olduğu görülmektedir.

Tablo 7. Psikolojik şiddetin cinsiyet değişkenine göre incelenmesi

\begin{tabular}{lllllll}
\hline & Cinsiyet & N & Mean & Sd & t & P \\
\cline { 1 - 5 } Psikolojik şiddet toplam puan & Kadın & 98 & 42,9184 & 10,53778 & \multirow{2}{*}{, 388} & \multirow{2}{*}{$699^{*}$} \\
\cline { 2 - 5 } & Erkek & 68 & 42,2059 & 13,08703 & & \\
\hline
\end{tabular}

Tablo 7’de görüldügü üzere, psikolojik şiddet boyutu ile cinsiyet değişkeni arasında anlamlı farklılık bulunmuştur $(\mathrm{p}<0.05)$. Kadın sporcuların psikolojik şiddet ortalamasının erkek sporculardan yüksek olması, kadın sporcuların psikolojik şiddete daha fazla maruz kaldığını göstermektedir.

Tablo 8. Ekonomik şiddetin cinsiyet değişkenine göre incelenmesi

\begin{tabular}{lllllll}
\hline & Cinsiyet & $\mathrm{N}$ & Mean & sd & t & P \\
\hline \multirow{2}{*}{ Ekonomik şiddet toplam puan } & Kadın & 98 & 9,4082 & 2,30569 & \multirow{2}{*}{$-2,194$} & \multirow{2}{*}{, $030^{*}$} \\
\cline { 2 - 6 } & Erkek & 68 & 10,1618 & 1,97454 & & \\
\hline
\end{tabular}

Tablo 8'de görüldüğü üzere, ekonomik şiddet boyutu ile cinsiyet değişkeni arasında anlamlı farklılık bulunmuştur $(\mathrm{p}<0.05)$. Erkek sporcuların ekonomik şiddet ortalamasının kadın sporculardan yüksek olması, erkek sporcuların ekonomik şiddete daha fazla maruz kaldığını göstermektedir.

\section{TARTIŞMA}

Çalışmanın amacı, profesyonel sporcularda fiziksel, psikolojik, ekonomik ve cinsel şiddetin cinsiyet değişkenine göre incelenmesidir. Bu amaç doğrultusunda elde edilen bulgular bu bölümde yorumlanmaya çalışılmıştır.

Fiziksel şiddet boyutunda, tokat atma ve tekme atma şiddet davranışı $\% 20,5$ oranında, fiziksel şiddeti uygulayan kişi olarak diğer (flört, arkadaş ve diğ.) seçeneği \%65,1 oranında, takım arkadaşına veya başka sporcuya fiziksel şiddeti uygulama oranı \%56,0 ve fiziksel şiddeti uygulayan kişi olarak antrenör seçeneğinin \%30,1 oranında olduğu tespit edilmiştir. Fiziksel şiddeti uygulayan kişi olarak antrenör seçeneğinin yüksek değerde olması da dikkat çekici bir bulgudur (Tablo 1). Spor kurumunda 
fiziksel istismar ile ilgili yaşanan bazı deneyimler diğer kurumlarda (aile, okul vb.) görülen deneyimlerle benzerlik göstermektedir. Tokat, yumruk, vurma, itekleme, sarsma gibi dayak altında kümelenecek davranışların yanı sıra, bir alet ile vurma, yapılan spora özgü cisim fırlatma gibi zarar verici davranışların olduğu bildirilmiştir (Çetin, 2019). Psikolojik şiddet boyutunda, sporcuların psikolojik şiddete maruz kalma oranı \%68,7, sporcular \%85,5 oranında antrenmana geç geldiğinde psikolojik şiddete maruz kaldığını belirtmiştir. Psikolojik şiddeti uygulayan kişi olarak antrenör \%41 oranında en yüksek değere sahip olduğu görülmektedir (Tablo 2). Usta çırak ilişkisi çerçevesinde oluşan hiyerarşi içinde iktidarı elinde bulunduran antrenör, çocuk sporcuların özel alanına müdahale etme gibi bir hakkının olduğu düşüncesine sahiptir. Tehdit, güç veya güven ilişkisiyle kurulan bu düzen, spor ortamından çocukların bedenleri üzerinde her türlü tasarrufa sahip olduğu fikri ile gelişmektedir. Eril bir söylemle gelişen bu ast-üst ilişkisi antrenörün dışındaki diğer aktörler (idareci, akran, masör vb.) ve farklı istismar şekilleri (fiziksel, duygusal, cinsel istismar, ihmal) ile devam edebilmektedir (Foucault, 2000). Cinsel istismar konusunda yapılmış çalışmalar faillerin büyük bir kısmının (\%98) sporcu ile doğrudan ilgilenen antrenör, öğretmen veya eğitimcilerden oluştuğunu göstermektedir (Brackenridge ve ark., 2008). Ekonomik şiddet boyutunda, sporcuların gösterdikleri performansın karşıllı̆ıında aldığı maddi kazancın $\% 74,1$ oranında tatmin etmediği, prim ve maaşların $\% 74,7$ oranında geciktirildiği veya verilmediği, takım içi ücret eşitsizliğin \%71,7 oranında olduğu, spor yaparak elde edilen ekonomik gelirin \%78,3 oranında yetersiz olduğu belirlenmiştir. (Tablo 3). Diğer şiddet türleri ile bağlantı içerisinde olan ekonomik şiddet olgusu, sporcuların yaşam kalitesini, performansını ve motivasyonunu etkileyen olumsuz bir faktördür (Kılıç, 2019). Cinsel şiddet boyutunda, takım arkadaşı veya başka bir sporcunun cinsel şiddete maruz kalma oranı \%69,9 oranında, sözlü cinsel şiddete maruz kalma \%35,5 oranında, özel bölgelere dokunma $\% 23,5$ oranında, cinsel şiddeti uygulayan kişi olarak antrenör seçeneği \% 27,7 oranında olduğu tespit edilmiştir. Cinsel şiddeti uygulayan kişi sorusuna diğer (flört, arkadaş ve diğ.) seçeneği \%39,8 oranında en yüksek değere sahiptir (Tablo 4). Elit bireysel sporcuların katıldığı bir çalışmada, cinsel istismar bulguları, genelde erkek antrenör ve mağdur kadın sporcu şeklinde gelişmiştir. Kadın görüşmeciler cinsel istismar olarak cinsiyetçi şaka, beden ile ilgili cinsel yorumlar, rahatsız edici kötü bakış ve ilişkiye zorlanmaya karşı korumasız kaldıklarını beyan etmiştir. Spor ortamlarında antrenör ve sporcunun yakın temasa bağlı beden ilişkilerinin yoğun yaşanması, rahatsız edici temas, masaj, sokulma, taciz gibi eylemler ile karşılaşmalarına neden olduğu belirtilmiştir (Çetin, 2019). Antrenörlük ihlallerinin yaklaşık \%80’i dolaylı niteliktedir (yani direkt olarak sporcuya yönelik değil), bu da genç sporcuların henüz tam olarak anlaşılmayan şekillerde zarar yaratabilecek istismar, ihmal ve şiddete maruz kaldıklarını göstermektedir (Raakman ve diğ., 2010). Türkiye’de değişik spor branşlarındaki elit bayan sporcuların karşılaştıkları cinsel taciz olaylarının araştırıldığı bir çalışmada, kadın sporcuların \%56,2'si cinsel tacize uğradıklarını belirtmişlerdir (Gündüz ve ark., 2002). Sporcularda fiziksel şiddete maruz kalma sorusuna olumsuz yanıt oranı yüksek olmakla birlikte, kadın sporcularda fiziksel şiddet değerinin daha yüksek olduğu görülmektedir (Tablo 5). Sporda yaşanan şiddet olaylarında saldırganlığa neden olan faktörler arasında cinsiyet farklılıkları, kültür düzeyi, seyirciler, karşılıklı ilişkideki tutum ve anlayış ile hakemin taraflı tutumu da bir etken olarak kabul edilmektedir (Mutza - Baurb, 2009). Sporcularda psikolojik şiddet boyutu erkek ve kadın sporcularda olumsuz yanıt oranı yüksek olmakla birlikte, kadın sporcularda psikolojik şiddet değerinin daha yüksek 
olduğu görülmektedir (Tablo 6). Bir antrenörün psikolojik şiddeti sporculara uyguladığında, mağdur olan sporcularda öfke, düşük öz-yeterlik duygusu, düşük benlik saygısı, kaygı, zayıf beden imajı, güven eksikliği ve aşağılanma duygusu, depresyon ve kendini küçümseme duyguları oluşur (Gervis ve Dunn, 2004; Kerr ve Stirling, 2013). Psikolojik şiddet boyutu ile cinsiyet değişkeni arasında anlamlı farklılık bulunmuştur $(\mathrm{p}<0.05)$. Kadın sporcuların psikolojik şiddet ortalamasının erkek sporculardan yüksek olduğu tespit edilmiştir. Kadın sporcuların psikolojik şiddete daha fazla maruz kaldığını söyleyebiliriz. (Tablo 7). Spor ortamlarında sporculara yönelik, eğitimin amacına ulaşmaması ya da başarısızlı̆̆ın getirdiği moral bozukluğu gerekçesi ile aşağılama, dalga geçme, isim veya lakap takma, bağırma ve küfür davranışlar ile spor kültürünün özelliklerini yansıtacak şekilde çocukların hedef tahtasına konulduğu görülmüştür. Yine rekabet, performans, hedef, başarı gibi değişkenlerden dolayı baskı oluşturma, tehdit, şantaj, sporcuyu görmezden gelme, ilgiden mahrum etme ve cezalandırma gibi antrenör eylemlerinin yoğun olduğu tespit edilmiştir (Çetin, 2019). Ekonomik şiddet boyutu ile cinsiyet değişkeni arasında anlamlı farklılık bulunmuştur $(\mathrm{p}<0.05)$. Erkek sporcuların ekonomik şiddet ortalamasının kadın sporculardan yüksek olması, erkek sporcuların ekonomik şiddete daha fazla maruz kaldığını göstermektedir (Tablo 8). Sporda ekonomik sınırlılık/yoksunluk yaşanması ekonomik şiddet olarak ortaya çıarken, sporda ekonomik şiddete maruz kalan sporcuların iyi bir performans sergilemesi zorlaşmaktadır (Kılıç, 2019). Taraftarların, oyuncuların, antrenörlerin ve ebeveynlerin bir takıma karşı sahip oldukları bağlılık, rakip takım taraftarlarının kötüye kullanılmalarına ve dolayısıyla şiddet içeren davranışlarda bulunmalarına yol açabilir (Jamieson ve Orr, 2009). Türkiye’de sporcuların cinsel taciz algıları ve deneyimlerine ilişkin yapılan bir çalışmada, kadın sporculara cinsel yaşam hakkında sorular sorulması (\%76), vücudu ile ilgili cinsiyetçi şakalar (\%66), övgü ya da yorum yapılması (\%71), erkek sporculara ise cinsel içerikli materyaller gösterilmesi (\%70), tekrarlanan istenmeyen flört teklifleri (\%51) ve müstehcen bakışlar (\%72) cinsel taciz davranışları olarak görülmektedir. Erkek sporcuların \%27'si soyunma odalarında cinsel tacize maruz kaldıklarını belirtirken, kadın sporcuların \%26,3'ü spor alanlarında cinsel tacize maruz kaldıklarını belirtmişlerdir. Kadın sporcuların \%24,2'si uyararak cinsel tacize tepki gösterdiklerini, \%24'ü tepki göstermediklerini ifade ederken, erkek sporcuların \%27’si cinsel tacizi şaka gibi algılayıp yok saydıklarını, \%11,2'si fiziksel tepki gösterdiklerini ifade etmişlerdir. Genel anlamda bu çalışma Türkiyede kadın ve erkek sporcuların cinsel taciz deneyimleri olduğunu ortaya koymaktadır (Özen, Emir ve Koca, 2018). Şiddete yönelik yapılan bazı çalı̧̧malarda, istenmeyen fiziksel temaslar, cinsel içerikli şakalar, iltifatlar, materyaller (e-posta, mektup, mesaj) 1srarcı teklifler, rahatsız edici kesintisiz bakışlar ve cinsel teklife uyulduğu takdirde bazı kazançlar sağlanacağı ya da uyulmadığı takdirde spor hayatı ile ilgili bedeller ödeneceği hakkında sporcuların, özellikle kadın sporcuların cinsel taciz deneyimleri olduğunu ortaya koymaktadır (Auweele ve Opdenacker, 2008; Fasting, Brackenridge ve Walseth 2007). Spor ortamlarında görülen fiziksel, psikolojik, ekonomik ve cinsel şiddet olayları çocuk sporcular açısından tehlike oluşmaktadır. Bu nedenle dünyanın birçok ülkesinde sporda çocuk koruma programları geliştirilmiş ve uygulanmaktadır. Sporda Çocuk Koruma Programı uygulamaları İngiltere örneği incelendiği bir çalışmada, İngiltere'de sporun yönetiminden sorumlu tüm (Federasyonlar, Olimpiyat komiteleri, spor kulüpleri gibi) bağımsız spor örgütleri için çocuk koruma programlarının yasal bir zorunluluk olduğu tespit edilmiştir (Parasız, Şahin ve Çelik, 2015). Sporcu ailelerin sporda çocuk koruma hakkında farkındalık düzeylerine ilişkin yapılan bir çalışmada, aileler 
sportif ortamların çocuk istismarı açısından korunaklı olmadığını düşünmekle birlikte, ailelerin \% 83.2' si antrenörler için sporda çocuk koruma programına ihtiyaç olduğunu düşünmektedir (Küçük, Arman ve Bozkurt, 2016). Sporcu ailelerin beklentileri üzerine yapılan bir araştırmada, ailelerin \%11.6’sı çocuklarının spora devam edebilmesi yönünde gördükleri engeller arasında antrenörlerin uygunsuz davranışlarını (aşağılama, şiddet, cinsel suiistimal vb.) göstermişlerdir (Pehlivan, 2009). Spor alanındaki, fiziksel, psikolojik, ekonomik ve cinsel şiddete yönelik yapılan bu çalışmalar bizim çalışmamızı destekler niteliktedir.

\section{SONUÇ}

$\mathrm{Bu}$ araştırma, profesyonel sporcularda fiziksel, psikolojik, ekonomik ve cinsel şiddetin cinsiyet değişkenine göre incelenmesi amacıyla yapılmıştır. Araştırmaya katılan sporcularda, fiziksel şiddet boyutunda takım arkadaşına veya başka sporcuya fiziksel şiddeti uygulama oranı ile fiziksel şiddeti uygulayan kişi olarak diğer (flört, arkadaş ve diğ.) seçeneğinden sonra sonra antrenör seçeneğinin yüksek değerde olduğu tespit edilmiştir. Sporcuların psikolojik şiddeti antrenör tarafından, antrenmana geç geldiğinde yaşadığı tespit edilmiştir. Ekonomik şiddet boyutunda, spordan kazanılan gelirin tatmin etmediği, prim ve maaşların geciktirildiği veya verilmediği, takım içi ücret eşitsizliğinin olduğu, spordan elde edilen ekonomik gelirin yetersiz olduğu belirlenmiştir. Cinsel şiddet boyutunda, takım arkadaşı veya başka bir sporcunun cinsel şiddete maruz kaldığı, sözlü cinsel şiddet ile özel bölgelere dokunmanın daha fazla yaşandığı belirtilmiştir. Cinsel şiddeti uygulayan kişi olarak diğer (flört, arkadaş ve diğ.) seçeneği en yüksek değerde iken antrenör seçeneği ise ikinci sırada olduğu tespit edilmiştir. Kadın sporcularda, fiziksel ve psikolojik şiddete maruz kalma oranının erkek sporculara göre daha yüksek olduğu tespit edilmiştir. Sporcuların psikolojik şiddet ve ekonomik şiddet boyutu ile cinsiyet değişkeni arasında anlamlı farklılık bulunmuştur. Kadın sporcuların psikolojik şiddete, erkek sporcuların ise ekonomik şiddete daha fazla maruz kaldığ tespit edilmiştir.

\section{ÖNERILER}

Şiddet türleri birbirini etkilemektedir. Bu nedenle sporcu aileleri, sporcunun kendisi, antrenör, beden eğitimi öğretmeni, malzemeci, tesis görevlisi gibi spora ortamında bulunan bireylerin spor etiği, spor ahlakı, şiddet ve boyutları konusunda bilgilendirilmesi, doğru spor kültürünün geliştirilmesi önerilmektedir. Sporda şiddet olaylarının önüne geçmek, çocukların spor yaparken güvende olmaları, fiziksel ve zihinsel olarak sağlıklı bir şekilde gelişmeleri ve spordan kopmamaları amacıyla Sporda Çocuk Koruma Programının, Spor Bakanlığı koordinatörlügünde tüm spor federasyonlarını da kapsayacak şekilde Sporda Çocuk Koruma ile ilgili yasal düzenlemeler genişletilmesi önerilmektedir. Spor yöneticileri ve antrenörlerin sporda şiddet ve sporda çocuk koruma eğitimlerine katılmaları zorunlu hale getirilmesi önerilmektedir. 


\section{KAYNAKLAR}

Acet, M. (2005). Sporda Saldırganlık ve Şiddet. İstanbul: Morpa Kültür Yayınları 78-80.

Arıkan, Y. (2007). Futbolda Şiddet ve Polis, Polis Bilimleri Dergisi, 9, 1-4.

Auweele, Y. V., Opdenacker, J., Vertommen, T., Boen, F., Van Niekerk, L., De Martelaer, K., \& De Cuyper, B. (2008). Unwanted sexual experiences in sport: Perceptions and reported prevalence among Flemish female student-athletes. International Journal of Sport and Exercise Psychology, 6(4), 354-365. https:// doi.org/10.1080/1612197X.2008.967.1879

Brackenridge, C. H., Bishopp, D., Moussalli, S., \& Tapp, J. (2008). The characteristics of sexual abuse in sport: A multidimensional scaling analysis of events described in media reports. International Journal of Sport and Exercise Psychology, 6(4), 385-406.. https://doi.org/10.1080/1612197X.2008.967.1881

Brackenridge, C., Tess K. and Daniel R. (Editors) (2012). Sport, Children's Rights And Violence Prevention: A Sourcebook on Global Issues and Local Programmes. Brunel University, London.

Bulut, B. (2012). Takım ve bireysel sporlarda 14-18 yaş sporculara uygulanan şiddetin boyutlarının araştırılması, Yüksek Lisans Tezi, Uludağ Üniversitesi, Eğitim Bilimleri Enstitüsü, Beden Eğitimi ve Spor Ana Bilim Dal, Bursa.

Çetin, E. (2019). Türkiye’de bireysel sporlarda çocuk istismarı: elit sporcular örneği, Doktora Tezi, Gedik Üniversitesi, Sağlık Bilimleri Enstitüsü, Beden Eğitimi ve Spor Ana Bilim Dalı, İstanbul.

Domhnall, M. (1996). Child Abuse in Sport, Sports Medicine, 30, 275-276. doi: 10.1136/bjsm.30.4.275-a

Fasting, K., Brackenridge, C., \& Walseth, K. (2007). Women athletes' personal responses to sexual harassment in sport. Journal of Applied Sport Psychology, 19(4), 419-433. https://doi.org/10.1080/104.132.00701599165

Foucault, M. (2000). Özne ve İktidar. İstanbul: Ayrıntı Yayınları.

Gervis, M., \& Dunn, N. (2004). The emotional abuse of elite child athletes by their coaches. Child Abuse Review: Journal of the British Association for the Study and Prevention of Child Abuse and Neglect, 13(3), 215-223. 13, 215-223. https://doi.org/10.1002/car.843

Gümüşdağ, H. (2004). Profesyonel futbolda fauller ve saldırganlık teorileri bakımından değerlendirilmesi, Doktora Tezi, Gazi Üniversitesi, Sağlık Bilimleri Enstitüsü, Beden Eğitimi Ve Spor Anabilim Dalı, Ankara.

Gündüz, N., Koz, M., Fedai, T., Sunay, H., \& Ersöz, G. (2002). Türkiye’de değişik spor branşlarındaki elit bayan sporcuların karşılaştıkları cinsel taciz olaylarının araştırılması. Spor Araştırmaları Dergisi, 6(1), 95-108.

Jamieson, L. M., \& Orr, T. J. (2009). Sport and violence: A critical examination of sport. Routledge.

Karasar, N. (2005). Bilimsel Araştırma Yöntemi, Ankara: Nobel yayın dağıtım, 77-83.

Kerr, G., Stirling A. (2008). Child Protection in Sport: Implications of An Athlete-Centered Philosophy. Quest, 60: 307-323. https://doi.org/10.1080/00336.297.2008.10483583

Kılıç, G. (2017). Kadın Akademisyenlerin Kadına Yönelik Ekonomik Şiddet Algısı: Düzce Üniversitesi Örneği, Yayınlanmamış Yüksek lisans Tezi, Cumhuriyet Üniversitesi Sosyal Bilimler Enstitüsü, Sosyoloji Ana Bilim Dalı, Sivas.

Kılıç, M. (2019) Sosyolojik Açıdan Sporda Şiddet Olgusu: Bütüncül Bir Bakış. Muhakeme Dergisi, 2(1), 83-98. https://doi.org/10.33817/muhakeme.468835

Küçük, V., Rodopman Arman, A. ve Bozkurt, S. (2016). Sporcu Ailelerinin Sporda Çocuk Koruma Hakkında Farkındalık Düzeyleri, Marmara Üniversitesi Spor Bilimleri Dergisi, 1 (2), 71-82. doi: 10.22396/ sbd.2017.17

Mountjoy, M., Brackenridge, C., Arrington, M., Blauwet, C., Carska-Sheppard, A., Fasting, K., \& Budgett, R. (2016). International Olympic Committee consensus statement: harassment and abuse (nonaccidental violence) in sport. British Journal of Sports Medicine, 50(17), 1019-1029. doi: 10.1136/ bjsports-2016-096121 
Mutz, M., \& Baur, J. (2009). The role of sports for violence prevention: sport club participation and violent behaviour among adolescents. International journal of sport policy, 1(3), 305-321. https://doi.org/10.10 80/194.069.40903265582.

Neugebauer, R. (2000). Research on intergenerational transmission of violence: the next generation. The Lancet, 355(9210), 1116-1117. doi: 10.1016/S0140-6736(00)02056-0.

Özen, G., Emir, E., Koca, C. (2018). Türkiye'de sporcuların cinsel taciz algıları ve deneyimleri. Spor Bilimleri Dergisi, 29(4), 157-177. https://doi.org/10.17644/sbd.523061.

Öztürk, F., Koparan, Ş., HAŞIL, N., Mehmet, E., \& Özkaya, G. (2004). Antrenör ve hakemlerin empati durumlarının araştıılması. Spormetre Beden Eğitimi ve Spor Bilimleri Dergisi, 2(1), 19-25. https://doi. org/10.1501/Sporm_000.000.0014

Parasız, Ö., Şahin, M.Y., Çelik, A. (2015). Sporda Çocuk Koruma Programı Uygulamaları: İngiltere Örneği, International Journal of Science Culture and Sport (IntJSCS), 3, Doi: 10.14486/IJSCS329

Pehlivan, Z. (2009). Spora Katılan Çocuklara Yönelik Ailelerin Beklentileri, Çocuklarda Gözlenen Davranış Değişimleri ve Spora Katılımın Önündeki Engeller, Spormetre Beden Eğitimi ve Spor Bilimleri Dergisi, 7 (2), 69-76. https://doi.org/10.1501/Sporm_000.000.0152

Polat, O. (2014). Klinik Adli Tip, 7. Baskı, Seçkin yayınları,112-117.

Raakman, E., Dorsch, K., \& Rhind, D. (2010). The development of a typology of abusive coaching behaviours within youth sport. International Journal of Sports Science \& Coaching, 5(4), 503-515. https://doi. org/10.1260/1747-9541.5.4.503.

Stirling, A. E., \& Kerr, G. A. (2013). The perceived effects of elite athletes' experiences of emotional abuse in the coach-athlete relationship. International Journal of Sport and Exercise Psychology, 11(1), 87-100. https:// doi.org/10.1080/1612197X.2013.752173

Şahin, M. H. (2003). Sporda Şiddet ve Saldırganlık, Ankara: Nobel Yayın Dağıtım, 56 - 163.

Tiryaki, Ş. (2000). Spor Psikolojisi, Ankara: Eylül Kitap ve Yayınevi.

World Health Organization. (2014). Strengthening the role of the health system in addressing violence, in particular against women and girls, and against children. Sixty-Seventh World Health Assembly Resolution. http://www.who.int/reproductivehealth/topics/violence/en (05.05.2021) 